原著

\title{
$\mathrm{X}$ 線検查による歯槽骨の客観的評価につレて （軟組織の画質に及ぼす影響）
}

\author{
石 原 彰 恭 \\ 東京医科雪科大学囷学部第二雨科保存学教室 (主任 : 指導 : 木下四郎教授) \\ 東京医科菌科大学歯学部歯科放射線学教室 (指導 : 中村 正教授)
}

(1976年 7 月 15 日受付)

\section{Objective Estimation of Alveolar Bone by Radiograph (influences of soft tissue on quality of imge)}

\author{
Akiyasu Ishihara \\ Department of Periodontology, School of Dentistry, \\ Tokyo Medical and Dental University \\ (Chief and Director : Prof. Shiro Kinoshita) \\ Department of Dental Radiology, School of Dentistry, \\ Tokyo Medical and Dental University \\ (Director : Prof. Tadashi Nakamura)
}

要旨 : 苗周疾患の術後経過をX線写真の黒化度の変化から客観的に観察しょうとする武みは数多く行われ てきている。すなわち, 撮影条件の再現性を期待するために, 幾何学的な規格が行われてきた。また, 黒化 度測定の尺度としてアルミニウムの階段が用いられたりしてきた。しかしながら, 歯周組織のX線像の黒化 度は, 硬組織と軟組織の双方によって与えられる。したがって黒化度測定による術後経過の客観的な把握の ためには，硬組織としての匊槽骨と，軟組織としての䍘肉の双方の変化を考えた上で行われなければならな い。ととろが従来の研究は, 軟組織の存在とその変化が黒化度に影響を与えるという観点からは行われてい ない。そてで著者は, 軟組織の存在そのものが黒化度に影響を与光るか, 否か, もし与元るとすればその内 容はどうであろうか, さらにてれを除去するための方法はどうであろうか, という立場から実験的研究を行 った。得られた結果としては，われわれが十分に観察したい場所である菌槽骨頂のように，薄い骨の黒化度 は僌組織によって影響されるてと，その物理的内容は散乱線によるものであるてとなどが明らかになった。 また，ての散乱線の影響をできるだけ少なくするためには，口内法では照射野を絞るととが好ましいととな どが明らかになった。

\section{目次}

I . 緒 言

II. 歯肉の厚みの測定と予備的実験
1. 歯肉の厚みの測定
1) 材料と方法
2) 結 果

2. 予備的実験 
1）装置, 材料および方法

2) 結 果

III. ファントームの選択とその減弱に関する検討

1. ファントームの選択
a) 軟組織ファントームについて
b）骨類似ファントームについて

2. 骨類似および軟組織類似ファントームの X 線の減 弱に関する検討
1）材料と方法
2) 結 果

IV．散乱線の影響に関する検討
1) 材料と方法
2）結 果

V. 臨床における散乱線の処理方法について

1. 材料と方法

2. 結 果

3. 小 括

VI. 考 察

VII. 結 論

文 献

\section{I．緒言}

$\mathrm{X}$ 線検査は, 近代歯科臨床において久くことの できない重要な位置を占めている。特に曾周疾患 の臨床においては, 歯周ポケットの存在の様相お よび歯槽骨の変化の把握が必要であるため，X線 検查はきわめて重要な情報の提供源となってい る。検査の対象を歯槽骨の変化に置いた場合, こ のX線検査は臨床的に最も有力な手段として用い られる。しかしながら，情報の提供および記録の ために用いられるX線つィルムの放射線像は，X 線束が患者に入射してX線フィルムに到達するま でに通過するすべての組織との相互作用の結果か ら成り立っている。必ずしも目的とする歯槽骨の みからの情報を提供しているとはいえない。

一方, X線写真に現れたある部分の黒化度の変 化をもって, 骨の変化の定量的観察の尺度として いる研究は数多く行われてきていて ${ }^{1 \sim 12)}, \mathrm{X}$ 線撮 影における幾何学的条件の規格化に関しては多大 の努力が払われてきた13 18)。しかしながら，X 線フィルムの黒化の程度を左右する最も大きな因
子はフィルムに到達するX線の量である。との量 は, $\mathrm{X}$ 線の物理学的条件と, $\mathrm{X}$ 線物理学的にみた これと相互作用する被験体の内容とによって決ま る。したがって, X 線写真上の像の黒化度の程度 をもって被験体の変化を定量的に観察しようとす れば, X線の物理的条件の規格化々被験体の構成 に関する検討との双方がなされなければ十分とは いえない。すなわち, 䍘周組織において, 黒化度 の測定によって歯槽骨などの硬組織の変化の経過 を客観的に把握するには, 硬組識としての歯槽骨 と, 軟組織としての茵肉の双方の変化を考えた上 でなされなければならない。茵周疾患治療をした のちに歯槽骨の変化を客観的に把握する手段とし てX線検査法を用いる場合, 従来の研究において は, 軟組織の存在とその変化が黒化度に影響を与 えるという観点からの追究, 検索が無視されてき た。本研究の目的は, 軟組織の存在そのものが黒 化度に及ぼす影響の有無, あるとすればその内 容, この影響を除去するための方法等について実 験的に検討することである。

\section{II. 歯肉の厚みの測定と予備的実験}

\section{1. 歯肉の厚みの測定}

歯周疾患の診断の際に, 被験体として取り扱わ れろのは歯槽骨, 特にその骨頂部と, 歯肉などの 組織である。実験に先立って, てれらに代わるべ き実験用のファントームが要求される。骨に関し ては, 従来から銅板, アルミニウム板, 特殊なプ ラスチックなどが，ファントームとして使われて きた 10,19 22)。また, 軟組織に関しては, 水, 生 肉, 加工肉などが使われてきた。

こてでは軟組織フォントームとしてソーセージ を選び，その量に関する目安を作るために，まず 以下の測定を行った。

1) 材料と方法

被験者は, 東京医科歯科大学蔝学部付属病院第 二保存科に来院した男性 7 名, 女性 10 名の計 17 名 で, 平均年齢32歳であった。測定部位は上下顎の 前柬部で, 左右の中切曾間の歯肉と, 中切歯・側 切䍘間の雬肉とした。 
A

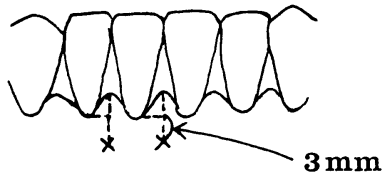

B

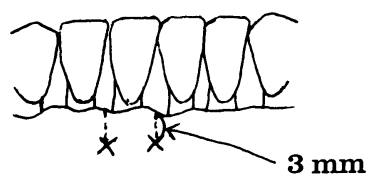

図 1 菌肉の厚みの測定と測定点 Aは正常歯肉および炎症歯肉で歯根露出のないもの Bは歯根露出のある場合で， メ印は測定点を示す Cは矢状断で, 縫合用直針が䨑肉面に垂直に刺入され, 䨑肉の厚みが測定される

測定部位をヒビテン液で消毒し, 浸潤麻酔し た。浸潤麻酔の刺入点は後の測定への影響を最小 限にするために, 歯肉歯槽粘膜移行部付近とした。 歯肉の厚みの測定方法は縫合用直針をピンセット で把持し，以下に述べる測定点において骨に達す るまで畨軸に垂直に刺入し，その刺入された長さ をノギスで測定した。測定点は, 図 1 亿示すよう に，正常曾肉を持つ者，および炎症はあっても歯 根露出を伴っていないものは, 右側の歯のセメン トエナメル境の高さの菌間部中央の点より $3 \mathrm{~mm}$ 根尖側の点とし, 歯根が露出しているものは, 歯 間乳頭の縁から $3 \mathrm{~mm}$ 下方の点とした。舌側も同 様とした。

\section{2) 結果}

測定点数は上顎 48 点, 下顎 52 点の計 100 点であ った。そのうち, 臨床的正常歯肉は36点, 中等度 炎症歯肉は 28 点, 高度炎症茵肉は 36 点であった。 得られた粷肉の厚みは表 1 亿示すように, 上顎唇

表 1 歯肉の厚みの測定值

( $\mathrm{mm})$

\begin{tabular}{c|r|r|r|r|r|r}
\hline & \multicolumn{3}{|c|}{ upper } & \multicolumn{3}{c}{ lower } \\
\cline { 2 - 7 } \cline { 4 - 6 } & Max. & Min. & Mean & Max. & Min. & Mean \\
\hline Lab. & 3.1 & 0.8 & 1.8 & 5.0 & 0.6 & 1.8 \\
Ling. & 3.5 & 1.1 & 2.5 & 4.5 & 1.0 & 2.2
\end{tabular}

側は最小 $0.8 \mathrm{~mm}$ ，最大 $3.1 \mathrm{~mm}$ で平均 $1.8 \mathrm{~mm}$ であ り, 上顎舌側は最小 $1.1 \mathrm{~mm}$, 最大 $3.5 \mathrm{~mm}$ で平均 $2.5 \mathrm{~mm}$ であった。下澦唇側は最小 $0.6 \mathrm{~mm}$, 最大 $5.0 \mathrm{~mm}$ で平均 $1.8 \mathrm{~mm}$ であり, 下顎舌側は最小 $1.0 \mathrm{~mm}$, 最大 $4.5 \mathrm{~mm}$ で平均は $2.2 \mathrm{~mm}$ であった。

\section{2. 予備的実験}

緒言で述べたでとく，歯槽骨骨頂部における軟 組織の存在が X線検査の対象となるととは理論的 に否定できない。X線写真の黒化度に，乙の軟組 織の存在がいかなる影響を及ぼすかについて, 通 常行われているように，骨の代用として銅板の階 段を作製し，歯肉の代用として市販のソーセージ を用いて，予備的実験を行った。

1）装置，材料および方法

A） X 線撮影装置：X線撮影装置はシーメンス 社製 Heliosphere 型 Type R. Tr. 88a （管電 圧 $40 \mathrm{kV}$ ，管電流 $10 \mathrm{~mA}$ ）を使用した。タイマー および時間的な出力の変動に関しては，通法によ るタイマー試験および電離層型線量計による検討 の結果, 本実験の精度の範囲では, それらの变動 は無視できた。

B）被験体およびフィルム：被験体としては,
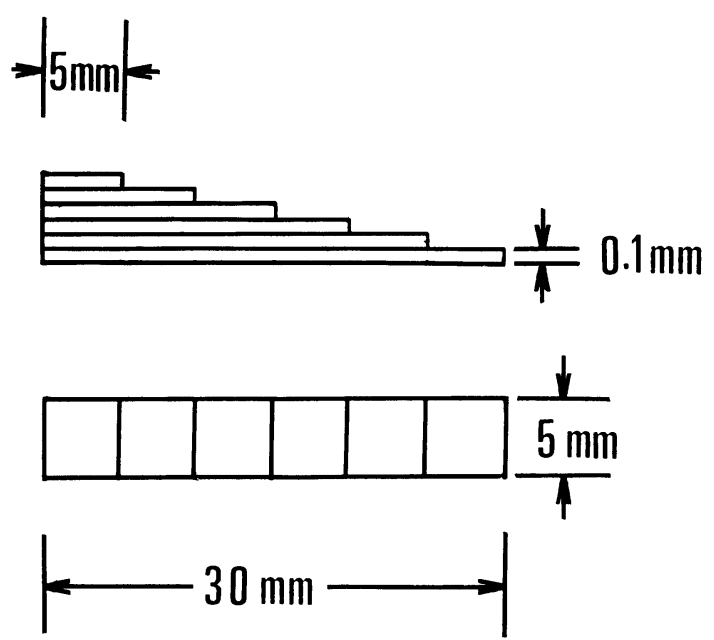

Cu-Steps

図 2 作製した銅製階段 


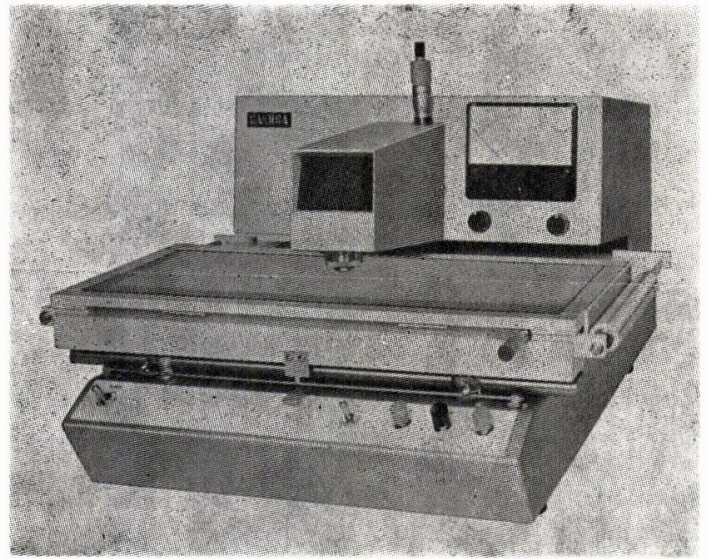

図 3 黒化度測定に使用したミクロフォトメーター PDS 15

図 2 に示すように厚み $0.1 \mathrm{~mm}$ の銅板を切断し, 縦 $30 \mathrm{~mm}$, 横 $5 \mathrm{~mm}$ の階段を作製し，その階段に 厚み $1 \mathrm{~mm}$ の市販のソーセージを重ねたものを用 いた。フィルムは阪神技術研究所製のシルバーフ ィルム門菌サイズ FMS-Mを用いた。

C) 写真濃度 (黒化度) 測定装置 : 写真濃度測 定に使用した装置は, 図 3 亿示すように, サクラ フィルム社製々クロフォトメーターPDS15 であ って, 測定結果は $\mathrm{X}-\mathrm{Y}$ レコーダー（横河電機製 ペンレコーダ Type 3047）に同時に記録した。 そクロフォトメーターのスリットは幅 $50 \mu$, 高さ $100 \mu$ とした。

上記の X 線撮影装置を用いて, 撮影条件を焦点 ・フィルム間距離 $27 \mathrm{~cm}$, 照射野直径 $50 \mathrm{~mm}$ の円 として下記の $\mathrm{A}, \mathrm{B}, \mathrm{C}$ の被験体の X 線撮影を行 い, 現像処理後, 黒化度測定を行った。

A. 銅製階段のみ

B. 銅製階段にソーセージ $1 \mathrm{~mm}$ 重ねたもの

C. 銅製階段にソーセージ $2 \mathrm{~mm}$ 重ねたもの 各被験体について露出を0.1秒，0.2秒，0.4秒， 0.8 秒，および1.6秒として撮影した。フィルムの 現像条件は次のように規定した。フジフィルム社 製のハイレンドール現像液とハイレンフィックス 定着液を用いて, 現像 $20^{\circ} \mathrm{C} 4$ 分, 停止 30 秒, 定着 6 分, 水洗30分でフィルムを処理し, 自然乾燥さ せた。

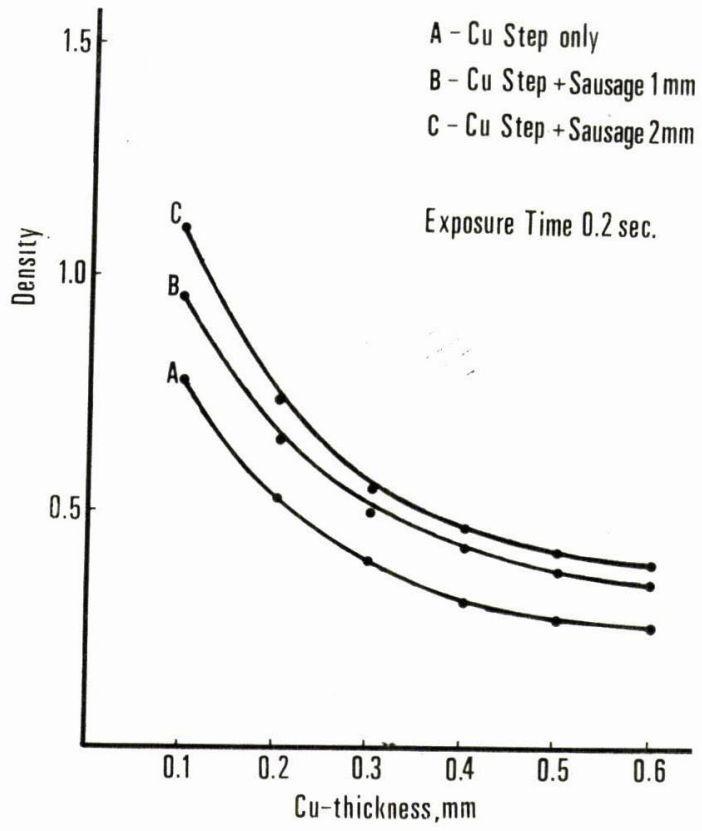

図 4 予備的実験のグラフ

以下の一連の実験においても，使用したX線撮 影装置, フィルム, ミクロフォトメーター, 現像 条件などは同一とした。

2) 結果

被検体として銅製階段のみのもの，乙れに厚み $1 \mathrm{~mm}$ のソーセージおよび $2 \mathrm{~mm}$ のソーセージを 重ねたものを露出時間を変えて撮影した結果, 黒 化度と露出時間との関係は図 4 亿示すとおりであ った。図 4 によれば，同一露出時間においては同 一の厚夕の階段の黒化度は, 厚み $2 \mathrm{~mm}$ のソー セージを重ねたもの，1 mmのソーセージを重ね たもの，銅製階段のみのものの順で低下してい た。

以上の結果から，一定の露出時間に対する銅製 階段の黒化度の変化はソーセージの存在によって 影響された。この事実は歯槽骨をX線写真で観察 する場合, それの示す黒化度が雬肉の存在によっ て影響を受け，さらに雪肉の厚みによってもまた 影響を受けるととを示している。得られた結果 は，フィルムの黒化が必ずしも透過X線のみによ って与えられないで, 被写体から発生する散乱線 
を考虑に入れて，上記のような軟組織の影響を検 討する必要があるてとをも示唆している。てれら の内容に関してさらに詳細な実験を計画した。

\section{III. ファントームの選択とその減弱に}

\section{関する検討}

\section{1. ファントームの選択}

a）軟組織ファントームについて

予備的実験において述べたごとく，市販のソー セージをもって歯肉にみたて，軟組織ファントー ムとした。

b ）骨類似ファントームについて

予備的実験において用いた骨類似ファントーム は銅製階段であった。乙の適否を以下のようにし て検討した。まず，成人の下顎前菌部の口内法 $\mathrm{X}$ 線写真を，銅製階段とともに撮影した。そのX線 写真について, 図 5 亿示すような走査線上をえク ロフォトメータで走査し, 各点の黒化度を測定し た。測定点は，Eはエナメル質，Dは象牙質，Pは

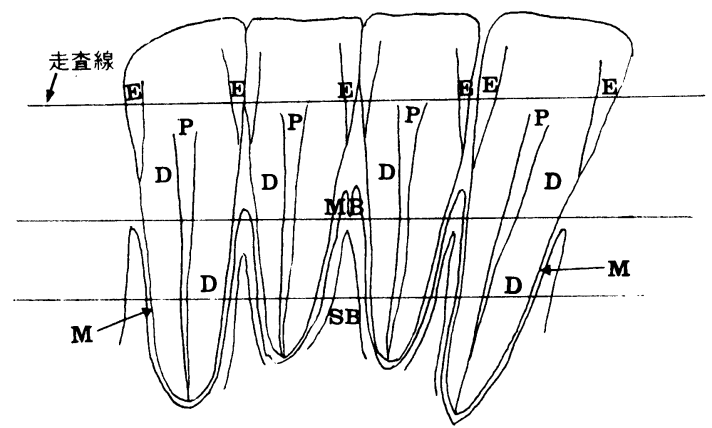

図 5 走査したX線写真の模式図と走查線を示す （図の略号の説明は本文中）。

表 2 成人下顎前菌部の黒化度の銅板換算値

(銅板換算値 : $\mu$ )

\begin{tabular}{c|r|r|r}
\hline \hline & Mini. & Max. & Mean \\
\hline E & 80 & 100 & 93 \\
D & 75 & 242 & 169 \\
P & 110 & 190 & 151 \\
M & 30 & 122 & 83 \\
M B & 73 & 143 & 88 \\
S B & 65 & 97 & 76
\end{tabular}

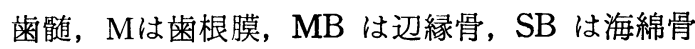
と読影できる点を意味する。同時に銅製階段の黒 化度を測定し, 各点の黒化度の銅板換算值を出し た。乙の結果，表 2 亿示すように，成人下顎前歯 部歯周組織の黒化度の銅板換算值は $30 \sim 200 \mu$ の 範囲にあり， $100 \mu$ 前後であった。したがって， 銅製階段では $200 \mu$ 以下の細かい黒化度の変化を 表現するためには，不適当であると考えられた。 そてで, 理想的ファントームの材料として, 硬質 プラスチックを選択し，本材料を用いて図 6 の $\mathrm{A} ， \mathrm{~B} ， \mathrm{C}$ のような 1 階段の厚みが $0.4 \mathrm{~mm}, 0.65$ $\mathrm{mm}, 0.8 \mathrm{~mm}$ の 3 種類の階段を作製した。これ

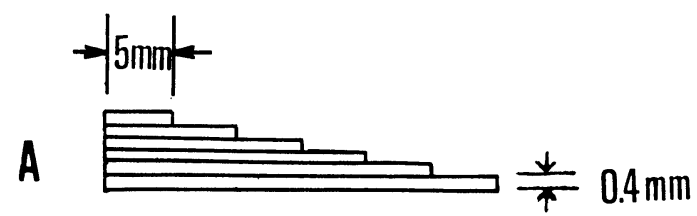

B

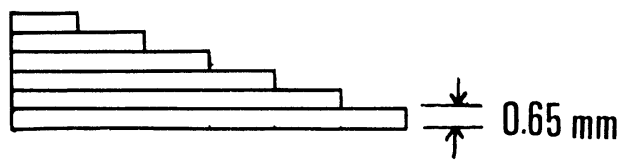

C
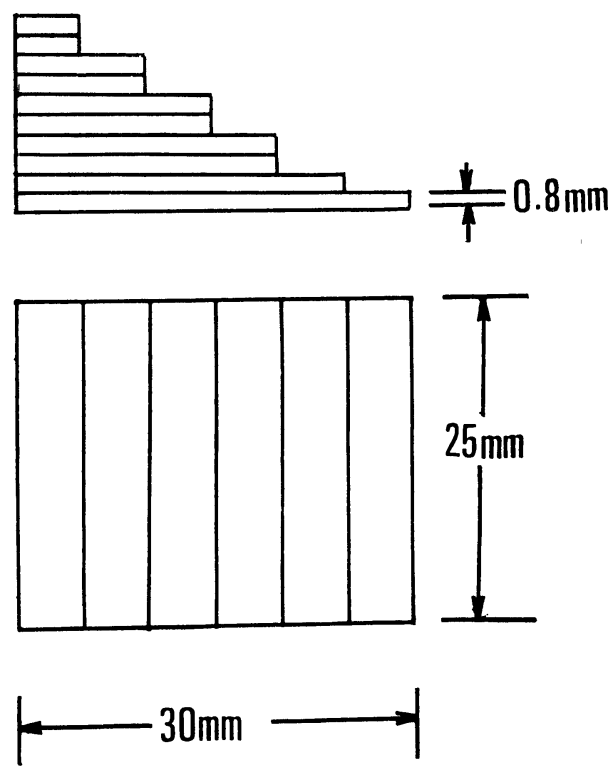

Plastic-Steps

図 6 硬質プラスチック板で作製した三種類の階段 


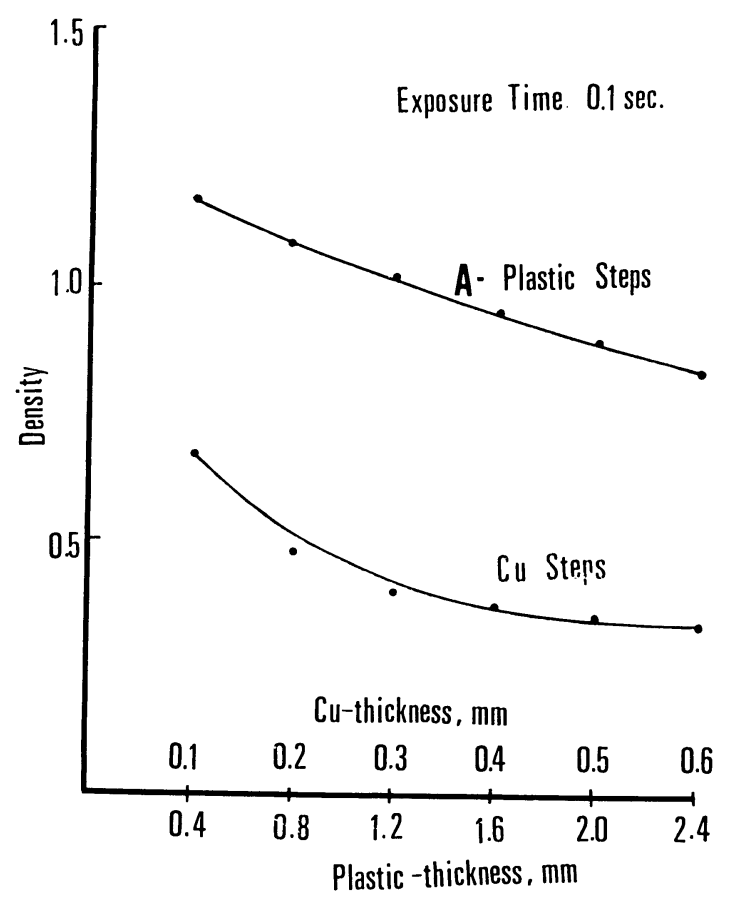

図 7-a

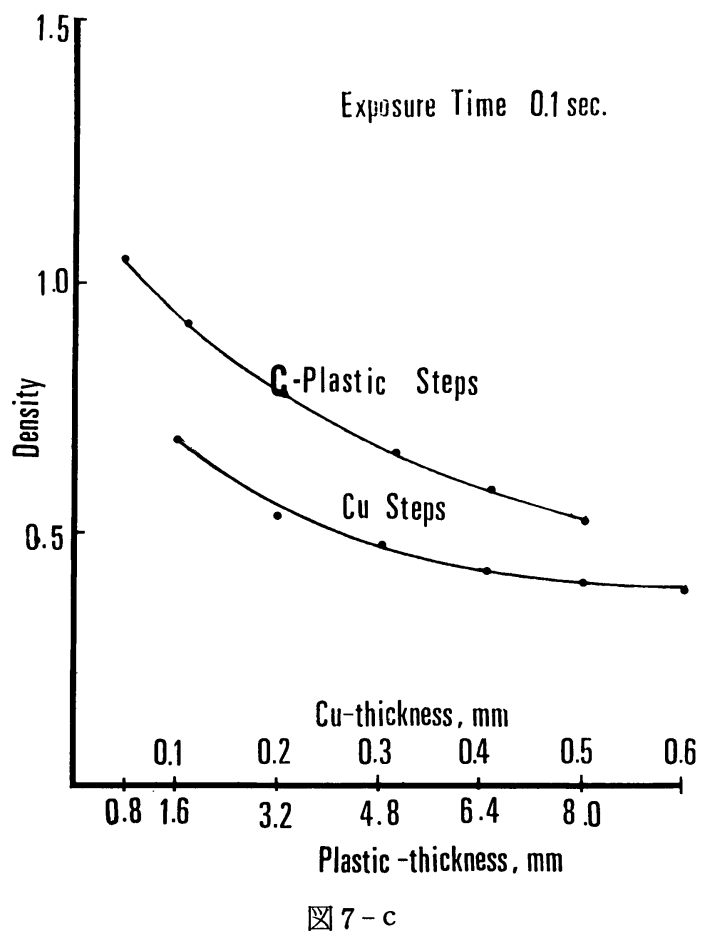

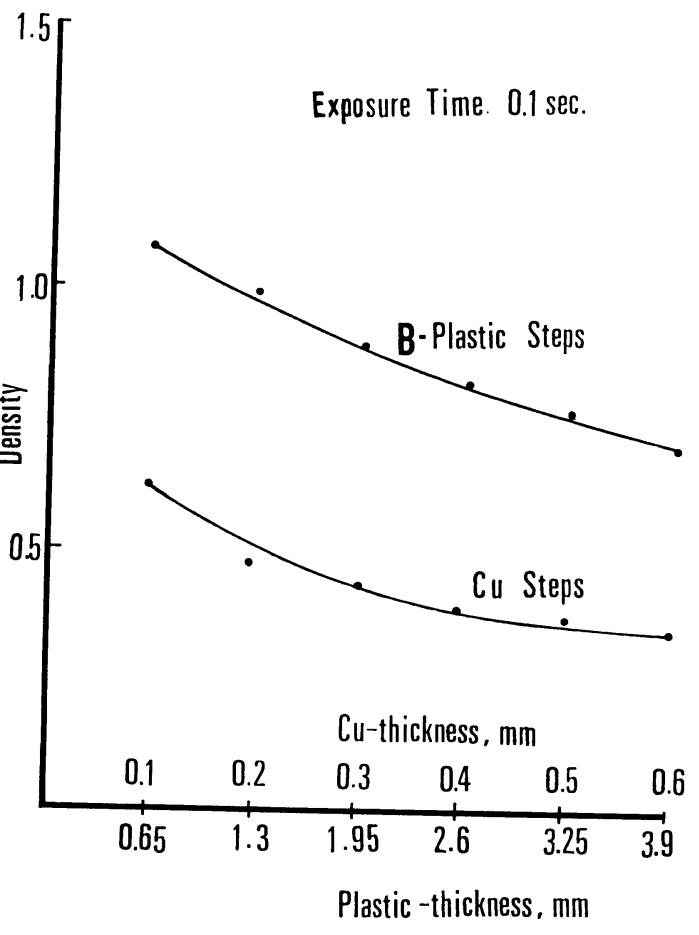

図 $7-b$

らを銅製階段と同時にX線撮影し，各階段の黒化 度を測定した。その結果, 図 7 の， b , c のグ ラフに示すように，階段 Cが，銅板の厚み $200 \mu$ 以下の範囲の黒化度を, 適当に表現できることが 明らかになった。そこで，階段Cを以後の実験の 骨類似ファントームとした。

2. 骨類似おょび軟組織類似ファントームの $\mathbf{X}$ 線の減弱に関する検討

予備的実験によると, 異なった 2 種類のファン 鉛絞 ク, $3 \mathrm{~mm}$ 鉛 Aperture, $5 \mathrm{~mm} \varnothing$
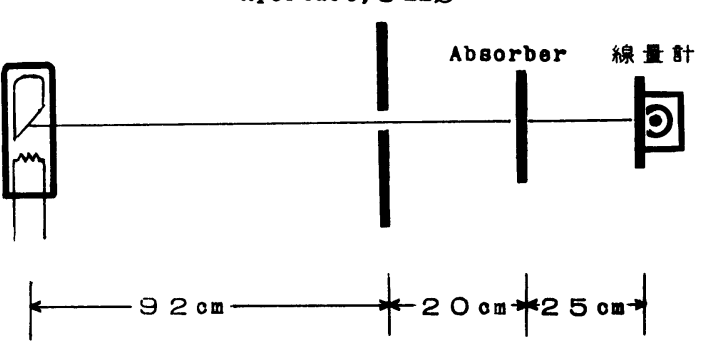

図 8 プラスチック板とソーセージの透過X線の減弱 を測定した実験系 
トームを組み合わせて撮影を行った場合, フィル ムの黒化度は上昇していた(図 4 )。てのてとは, 被検体の増加によって透過 X線は減少するはずで あるという観点からは解釈ができなかった。そこ で， 2 種類のファントームを組み合わせた場合の 透過 X線の量の変化を詳細に検討するために, 次 のような実験を行った。

A) $\%$

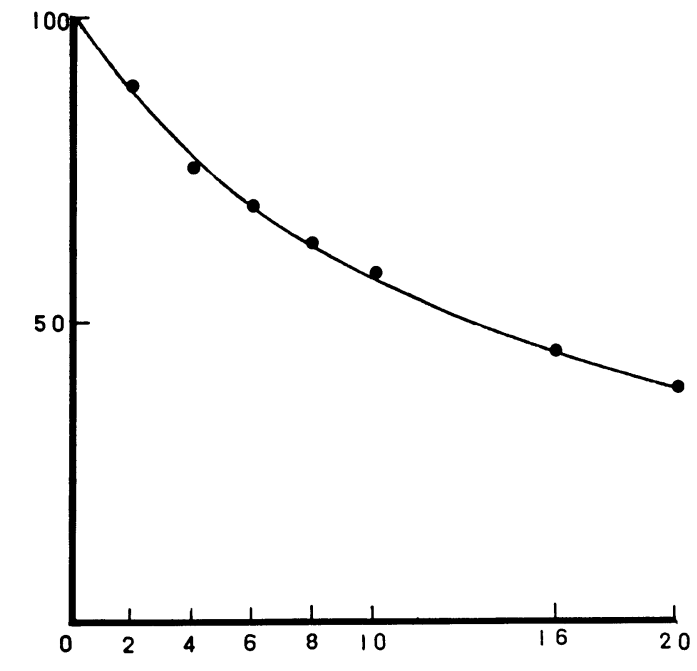

B) $\%$

Sausage-thickness, $\mathrm{mm}$

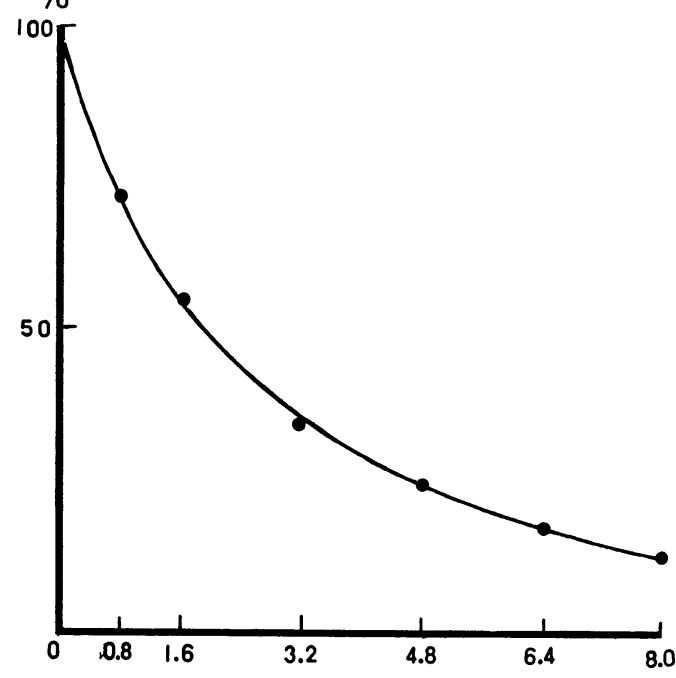

Plastic-thickness, $\mathrm{mm}$

図 9 ソーセージとプラスチック板の透過 X線の減弱 曲線
1) 材料と方法

透過X線の量は, 図 8 亿示すように, いわゆる “good geometry”下で測定した。実験の幾何 学的配置は, 次のとおりであった。すなわち, 焦 点・鉛絞り間 $92 \mathrm{~cm}$, 絞りの直径 $5 \mathrm{~mm}$, 鉛の厚 み $3 \mathrm{~mm}$, 鉛絞り・線量計間 $45 \mathrm{~cm}$, Absorber • 線量計間 $25 \mathrm{~cm}$ とした。用いた線量計は英国ピッ トマン社製 X-ray ドジメータ・モデル $37 \mathrm{C}$ ，チ ェンバーモデルA37Aであった。

2) 結 果

得られた透過 $\mathrm{X}$ 線の減弱曲線は図 9 の $\mathrm{A}, \mathrm{B}$,

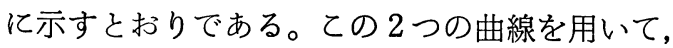
任意の厚みの骨類似ファントームに，任意の厚み の軟組織ファントームを重ねた場合の透過 X線の 減弱を合成した。その合成曲線を図10に示す。乙 れによると，骨類似ファントームの厚みを一定と すれば, これに軟組織ファントームを重ねた場 合, 軟組織の厚みが増すにつれて, 透過 $\mathrm{X}$ 線の量 は減少しており，予備的実験にみられたような場

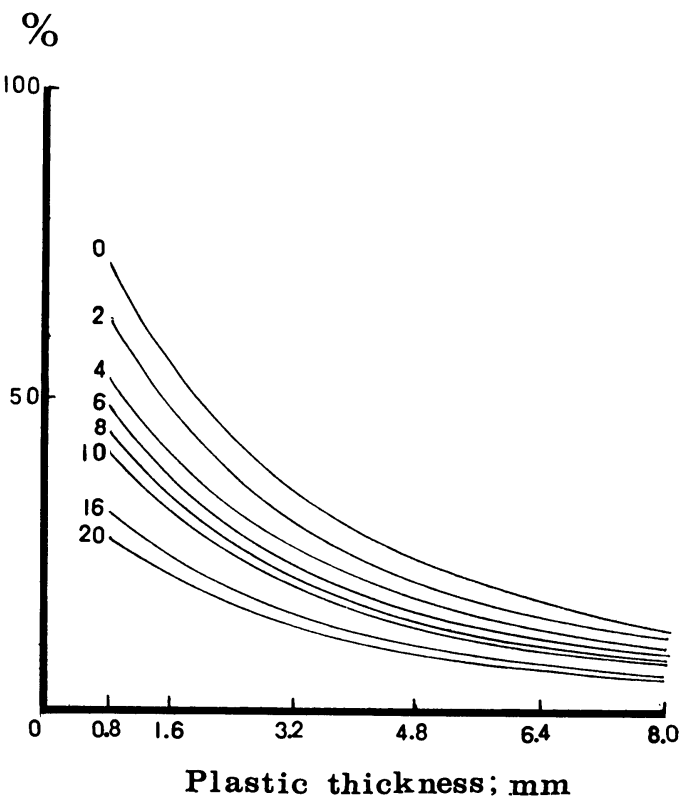

図10 プラスチック板にソーセージを重ねた場合の 減弱曲線（合成）

グラフの曲線の肩の数字はソーセージの厚さ を示す 
合はありえなかった。

\section{IV．散乱線の影響に関する検討}

予備的実験における撮影の幾何学的条件は, 被 写体・フィルム間距離がゼロであった。てのよう な “poor geometry” の状態で, フィルムがX線 の被爆を受ける時には，X線物理学的に，散乱線 は無視しえない。したがって，予備的実験の結果 は，透過X線のみではなく，散乱線の存在も考虑 して検討される必要がある。

X線の照射を行った場合，対象が皮膚の反応で あっても, 写真の黒化度であっても，乙れらに及 ほす散乱線の影響の有無，およびその大小に関す る実験は，X線の物理的条件を変えずに，照射野 の大きさを変えて検討するのが通法である。本研 究においてもての方法によって散乱線の影響を検 討した。

1) 材料と方法

被写体としては硬質プラスチック製骨類似ファ ントーム（図 6 のC）と軟組織ファントームとし てのソーセージを用い, 撮影条件は予備的実験と 同一とした。また，照射野を厚み $3 \mathrm{~mm}$ の鉛板で 変化させ, 各照射野について露出を変えた上で,

一定露出時間に対してソーセージの厚みを $2 \mathrm{~mm}$ から $20 \mathrm{~mm}$ まで変えた。ての厚みは，歯肉の厚み を参考にした。厚さ $16 \mathrm{~mm}$ と $20 \mathrm{~mm}$ の場合はそれ

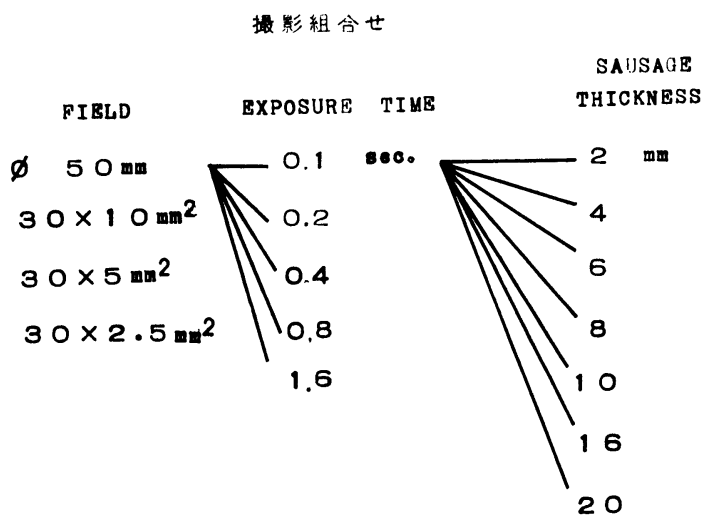

図11 散乱線の影響についての実験における照射野 の大きさ, 露出時間, ソーセージの厚みの組 み合わせ
ぞれ口唇および煩の厚みを考虑した場合である。 照射野の大きさ，露出時間，ソーセージの厚み の組み合わせは図11に示すとおりである。

2) 結 果

結果の代表的なものは図12１7のグラフに示す とおりであった。すなわち, 照射野が直径 $50 \mathrm{~mm}$ の円の時は, 露出が 0.1 秒, 0.2 秒, 0.4 秒の時, ソーセージを重ねることによる黒化度の変化に規 則性はみられず，図12のa)とb)に示すように，同 じ厚みのソーセージを重ねても露出によっては黒 化度を低下させたり上昇させたりしていた。露出 が 0.8 秒になると, 図13に示すように, ソーセー ジの厚みが増すにつれて規則的に黒化度が低下し

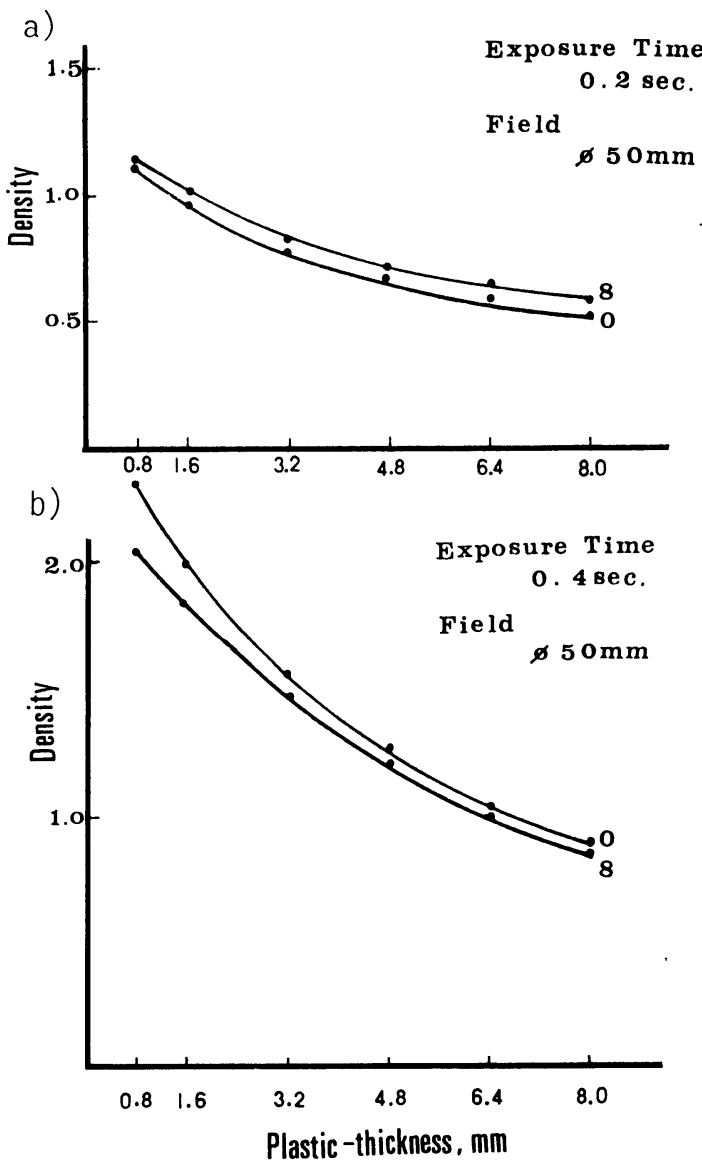

図12 照射野が $\phi 50 \mathrm{~mm}$ の円の時で，a）は露出が 0.2 秒 b) は0.4秒の時のソーセージの厚み $8 \mathrm{~mm}$ で の黒化度への影響を示す 


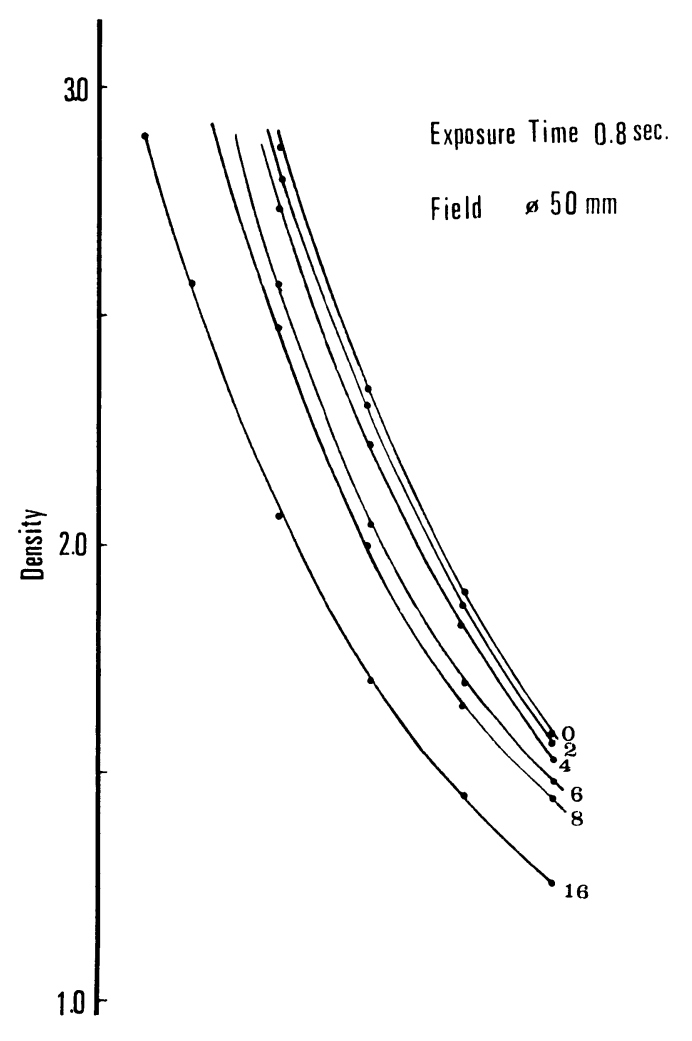

$\begin{array}{llllll}0.8 & 1.6 & 3.2 & 4.8 & 6.4 & 8.0\end{array}$

Plastic -thickness, mm

図13照射野が $\phi 50 \mathrm{~mm}$ の円で露出が 0.8 秒の時の グラフ, 曲線の脇の数字はソーセージの厚み を示す。単位は $\mathrm{mm}$ で, 以下のグラフでも同 様である。

ていた。照射野が長方形で $30 \times 10 \mathrm{~mm}^{2}$ の時は図 14のグラフに示すように, 露出が0.1秒では規則性 がみられず，露出が 0.2 秒， 0.4 秒の場合も同様に 規則性がみられなかった。露出が 0.8 秒になると 図15のグラフに示すように,ソーセージの厚みが 増すにつれて規則的に黒化度が低下していた。照 射野が $30 \times 5 \mathrm{~mm}^{2}$ の時は図16のグラフに示すよ うに, 各露出において, 黒化度の低下に幾分規則 性がみられた。照射野をさらに狭くして $30 \times 2.5$ $\mathrm{mm}^{2}$ にした場合は, 図17に露出 0.4 秒の場合を示 してあるが, 各露出において,ソーセージの厚みが 増すにつれて，黒化度は規則的に低下していた。

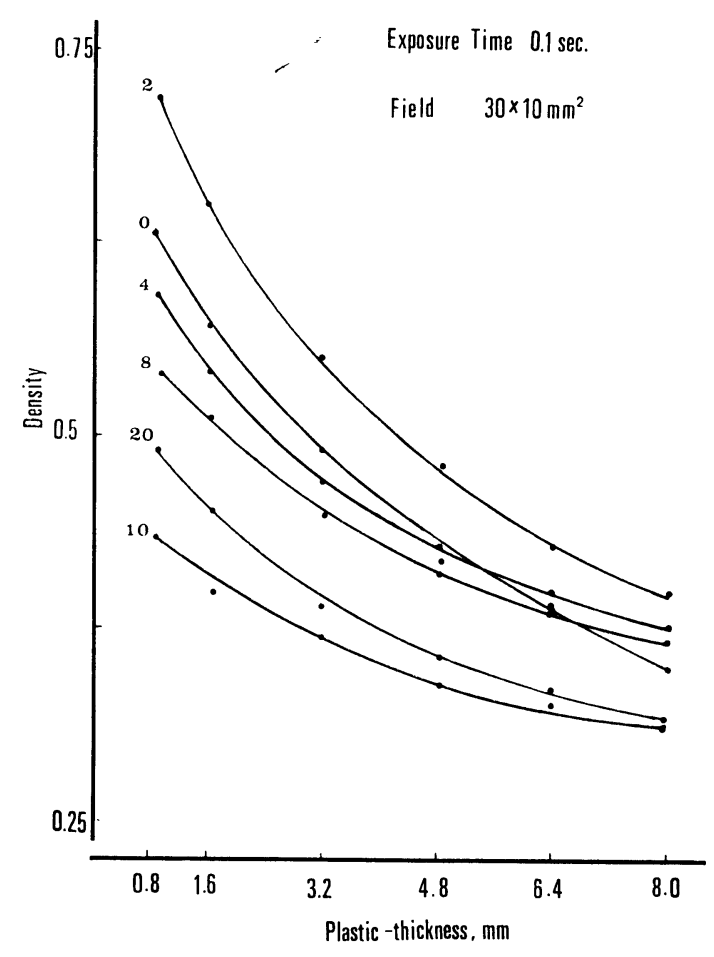

図14 照射野が $30 \times 10 \mathrm{~mm}^{2}$ で, 露出が 0.1 秒の時の グラフ

\section{V. 臨床における散乱線の処理方法について}

てれまでの実験によって, 口内法X線写真にお いて, 軟組織の存在は無視できないものとなっ た。その影響は軟組織の厚みと，それから発生す る散乱線によって生ずるてとが明らかになった。 そてで, 実際の臨床X線写真において, 歯槽骨の ような薄い骨に対する茵肉の黒化度への影響はど うであるかを検討するために次の実験を行った。

\section{1. 材料と方法}

歯周組織の黒化度を測定した実験の方法と同様 に, 正常な歯周組織を有する男性 2 名の下顎前歯 部のX線写真を撮影した。撮影条件として露出は 0.4 秒とし，その他はてれまでの実験と同様にし， 下記の条件のみを変えた。

a . 通常の口内法撮影法による

b. 通常の口内法撮影法によるが, 下口唇を下 方に翻転して撮影する 


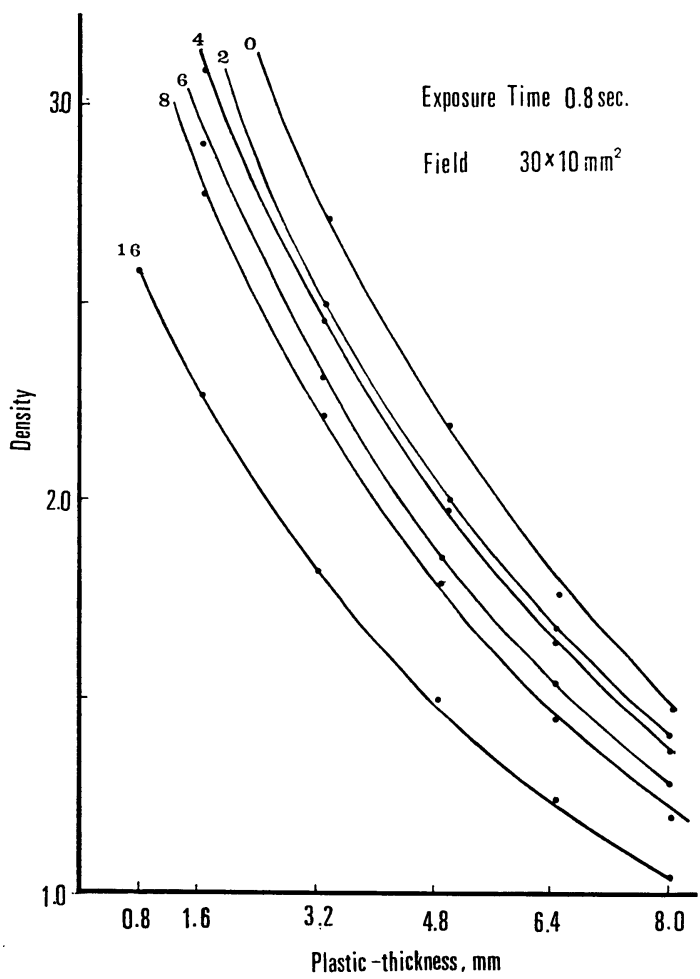

区15 照射野が $30 \times 10 \mathrm{~mm}^{2}$ で, 露出が 0.8 秒の時 のグラフ

c.bの状態において, 照射野を $20 \times 15 \mathrm{~mm}^{2}$ にして撮影する。

得られたフィルムの歯槽骨頂部の黒化度を測定 した。

\section{2. 結 果}

結果は, 表 3 に示す通りである。被験者 $\mathrm{A} の \mathrm{X}$ 線写真は図18に示す。黒化度は口唇の重なりを除 去すると上昇し, その状態で照射野を絞ると低下 した。

表 3 被験者 2 名の下䪽前歯部の歯槽骨頂部の黒化 度

（黒化度単位：D）

\begin{tabular}{|c|c|c|c|c|c|}
\hline & 被 験 者 & A & 被 & 験 者 & B \\
\hline a の方沫 & 1.08 & 1.03 & 1.33 & 1.08 & 1.18 \\
\hline $\mathrm{b}$ の方法 & 1.37 & 1.30 & 1.46 & 1.32 & 1.28 \\
\hline c の方法 & 1.17 & 1.10 & 1.33 & 1.20 & 1.16 \\
\hline
\end{tabular}

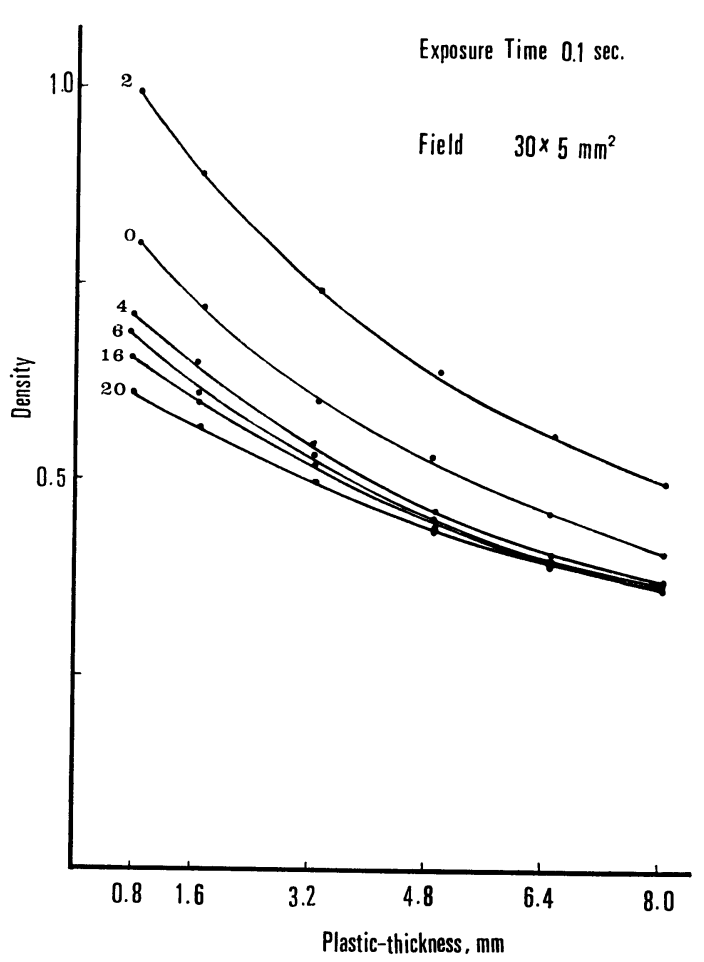

図16 照射野が $30 \times 5 \mathrm{~mm}^{2}$ で, 露出が 0.1 秒の時のグ ラフ

\section{3. 小 括}

模型実験によって, 軟組織の黒化度に対する影 響は無視できないてと，その修飾原因は散乱線に あることが示された。それと同様に実際の臨床写 真においても，散乱線の影響は大きく，ての影響 を除去するには照射野をある程度絞って撮影すれ ばよいととが明らかになった。

\section{VI. 考察}

歯周疾患の治療経過やその他の歯科治療後の経 過をX線写真によって経時的にとらえる研究は, 現在まで多くの研究者によって行われてきてい る。異なった時期に同一部位を撮影したX線写真 は被写体に対するフィルムの位置や照射方向がそ のつど異なるために，同じ規格による写真は得ら れず,その読影や比較において信頼性にそしく,間 


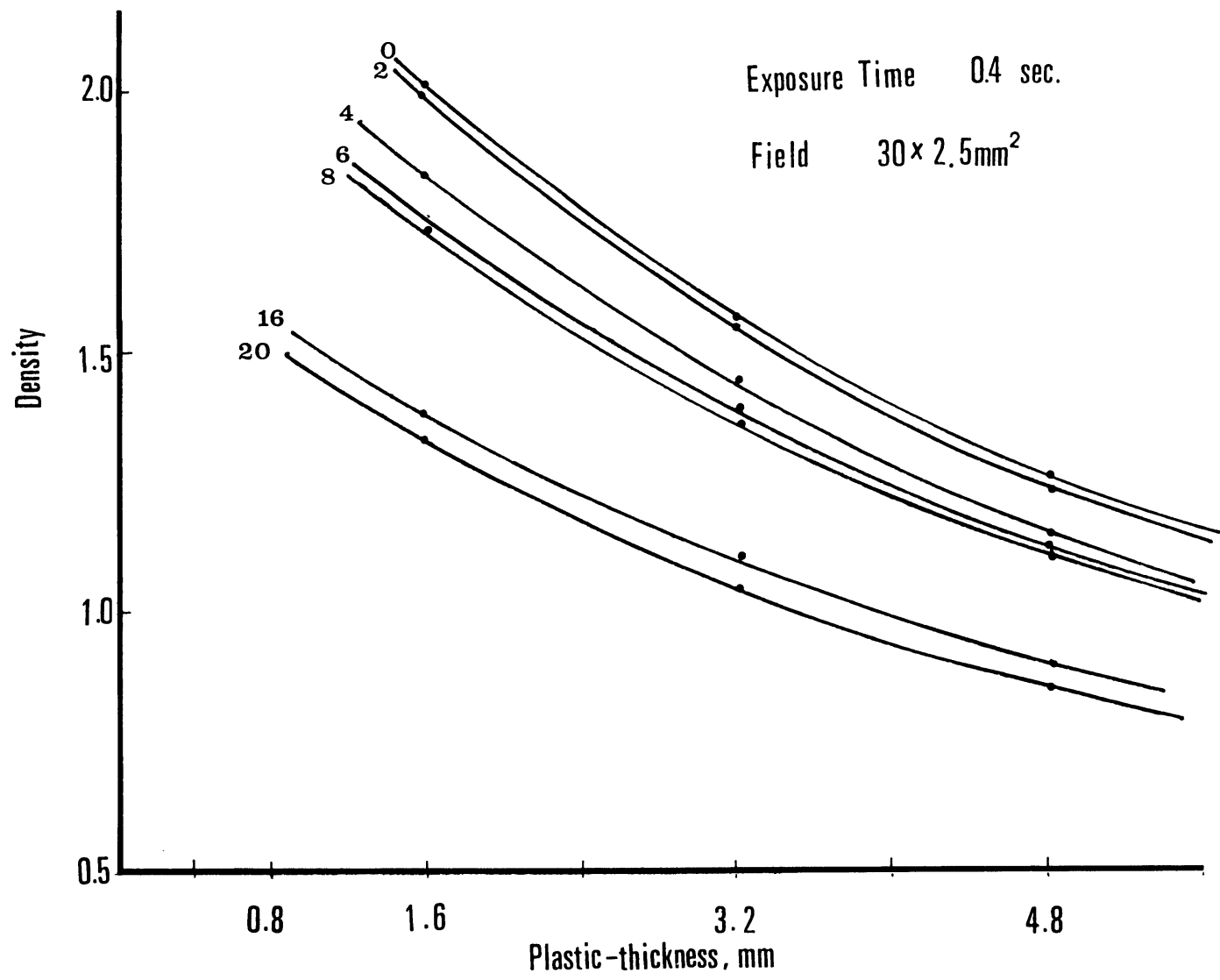

図17 照射野が $30 \times 2.5 \mathrm{~mm}^{2}$ で, 露出が 0.4 秒の時のグラフ

違った判定を下すような危険性もありうる。そ てでてのような欠点を避けるために撮影法の規格 化の必要が生し， Patur ${ }^{15)}$ らは被写体に対する フィルムの位置と X 線の照射方向との幾何学的関 係を常に一定にできる個体 $\mathrm{X}$ 線規格撮影装置を考 案し, 臨床に応用している4,6,10,12,16 18)。その 後てれらの装置は種々の面で改良が加えられてき ている。また, 歯周疾患の臨床において得られた $\mathrm{X}$ 線写真の分析については, 従来は肉眼的にみた 黒化度の変化や, 歯槽骨頂の位置の変化 ${ }^{4)}$ などで 評価されていたが, 近年では濃度計を利用して X 線写真上の黒化度を測定するてとによって, 術後 の変化を評価する傾向になってきている ${ }^{3,5,7,8,10 \sim ~}$ 12)。しかしながら, 歯周組織の X 線像の黒化度は 硬組織と軟組織の双方によって与えられる。した
がって黒化度測定による術後経過の客観的な把握 は，硬組織としての歯槽骨と軟組織としての歯肉 の双方の変化を考えた上でなされなければならな い。ところが従来の研究は, 軟組織の存在とその 変化が黒化度に影響を与えるという観点からはな されていない。そこで著者は軟組織の存在が黒化 度に及ぼす影響を詳細に検討した。まず，実際に 存在し，画質に影響を及ぼしていると思われる軟 組織, すなわち曾肉の厚みを測定した。藤田 ${ }^{23)}$ 亿 よれば, 歯肉の厚みというものは $1 \sim 3 \mathrm{~mm}$ で, 概して口腔前庭側, 特に歯槽隆起部で薄く, 口腔 側, 特に上顎の口蓋側で厚いと述へている。牧 ${ }^{24)}$ は日本人成人 68 屍で, 付着歯肉の厚みを調査して いる。著者の測定值と牧の值とを比較検討してみ ると, 上顎においては同傾向を示している。下顎 


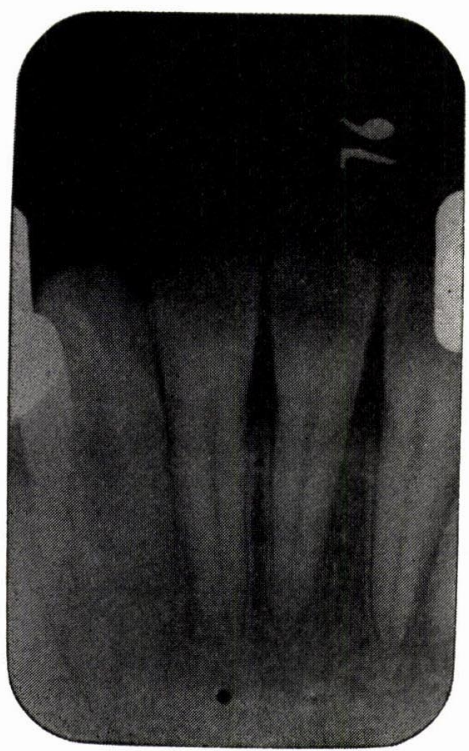

$\mathrm{A}$ の方法

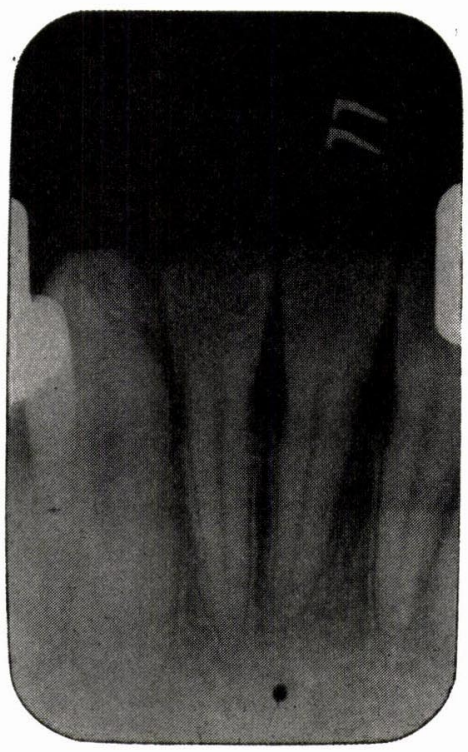

$\mathrm{B}$ の方法

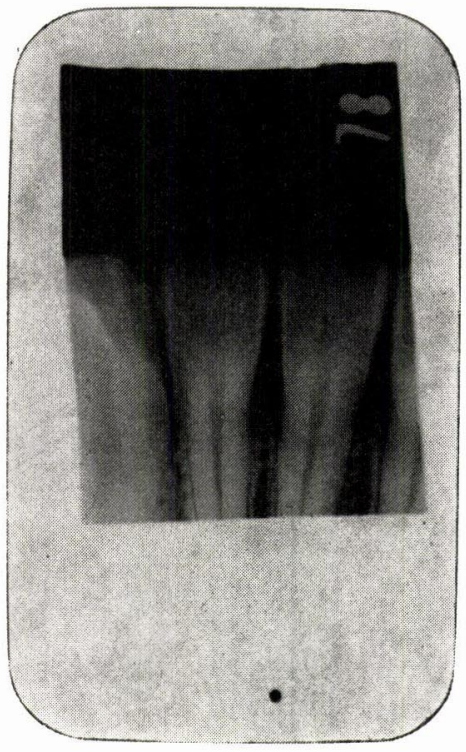

Cの方法

図18 被験者 $\mathrm{A} の \mathrm{X}$ 線写真

については, 本実験では舌側よりも煩側が $0.4 \mathrm{~mm}$ 程度厚いという数值がでた。牧は下顎は舌側と煩 側の曾肉の厚みがほぼ同じであったと述べてい る。乙れは測定点が牧よりも根尖寄りに位置して いるためと思われる。これらの測定值を参考にし てソーセージによる軟組織ファントームを作製し た。次に骨類似ファントームについてみると, 過 去においてはアルミニウム, 石こう, 銅板, マグ ネシウム，プラスチック板に骨粉を封入したも の19)などが用いられてきている。また, その形状 の均等なものとして, あるいは一端を厚く, 他端 を薄くした階段にしたものを利用しているが25), 本実験ではまず銅板で階段を作製し，予備的実験 を行った。その結果，てれが厚みおよび口腔内X 線写真像の黒化度の幅の点で適当でないことが判 明したので，硬質プラスチック板で適当な階段を 作製した。

一般にX線は物質を通過することによって吸収 され, その強さを減弱し, フィルムの黒化度は低 下する。その吸収される程度は, 対象物質の構成 要素や厚みなどの物理的性状によって異なる。と ころが予備的実験における結果は, フィルムの黒
化の原因が透過 $\mathrm{X}$ 線のみによる被爆と考えられる ような条件下で行われたと想定される実験結果と は明らかに相反した。フィルムが被写体と密着し ているような通常の X 線撮影における幾何学的 条件下では, フィルムの黒化の原因は透過 X 線 と, 被写体から生ずる散乱線によるものと考えら れている。しかも散乱線の黒化に対する寄与はき わめて大きい場合がある。予備的実験の結果の 分析に関しても, 散乱線の影響を除外するてとは 当然不合理であった。そこでその影響を確認し， 除去方法についても検討した。その結果, 黒化度 上昇の原因は被写体（ソーセージ）から発生する 散乱線であるととが判明した。一般にフィルム に到達する散乱線は, (1)入射光線のエネルギー, (2)検査に用いられる照射野の面積と形, (3)検査物 質の厚み, (4) X線像面と散乱源との間の距離など の因子によって複雑に左右される ${ }^{26)}$ 。照射野が増 加すれば, 散乱 X線光子の発生する確率が増し, 吸収体の厚みが増せば，また同じうな効果を生 ずる。ところが散乱線の像面に達する確率は増加 するとは限らない。したがって骨類似ファントー ムにソーセージを重ねて, 種々の条件で撮影した 
図12〜17のグラフは，乙れらの(1)〜3)の因子が複 雑に相互に影響し合ってフィルムに達する散乱線 量に変化を与えた結果であり，それぞれを単独の 因子で原因づけろことは困難であると思われる。

てのように画質に多大な影響を及ぼしている軟 組織は, 黒化度測定による歯周疾患の処置後経過 の判定の際無視するてとはできない。その原因は 散乱線であることが判明したが，その除去方法に ついて考えてみると，(1)，グリッドの使用，(2)鉛 マスクで照射野を絞る方法, (3)金属八ク片をフィ ルムの前におく方法（透過X線を吸収しないくら い無限に薄く, 表面にあたった散乱線を完全に吸 収するようなものが理想である)，(4)被検体とフ ィルム間の距離を離す方法（鮮鋭度は減少する） などが考えられる27)。(1)，(4)の方法については， 鮮鋭度を目的としている口内法 X線写真では不可 能であったので, 本実験では(2)の鉛板で照射野を 絞って, 散乱線量を減少させる方法を使用した。 その結果，ある程度まで照射野を絞って撮影する と, 無視できろ程度にまで散乱線が減少し, 軟組 織の厚みの影響が規則的な黒化度の変化として現 れた。

てれらの結果を総合して考えてみると, 実際の 臨床X線写真においても, 軟組織の存在は散乱線 のために黒化度を上昇させたり，ある時は低下さ せたりしていると推定でき, また臨床的にも影響 を与えているてとが判った。ての黒化度に対する 影響を規則的にするために，ある程度照射野を絞 って撮影する必要があると思われる。また,さら に一歩進んで, 軟組織の規格化の可能性の追求が 今後の課題として残されている。

\section{VII. 結 論}

歯周疾患の治療後の歯槽骨の変化を, 口内法 X 線写真によって, 客観的に評価する場合に, 軟組 織の画質に及ぼす影響について，研究を行い，下 記のような結果を得た。

(1) 軟組織ファントームの目安とするために, ヒト柬肉の厚みを測定した。前歯部の歯肉の厚み は,上下䫟とも, 平均 $2 \mathrm{~mm}$ 前後であった。
(2) 予備的実験によって，硬組織ファントーム としての銅製階段の黒化度は, 軟組織ファントー ムとしてのソーセージの存在によって, 影響され た。その様相は, 透過 X線のみならず，散乱線を も考虑に入れる必要のあることを示唆した。

(3) 骨類似ファントーム作製の目安とするため に, 実際の菌周組織の黒化度を測定した。成人下 顎前歯部の霜周組織の黒化度は, 銅板換算值で $100 \mu$ 前後であった。

(4) 骨類似および軟組織類似ファントームの減 弱率の測定と, 双方の減弱曲線の合成曲線から, 予備的実験の結果は, 散乱線の影響によるもので あることが確認された。

(5) 骨類似ファントームに対する軟組織の影響 を検討した結果，次のようであった。

(1)硬質プラスチック板に対するソーセージの黒 化度への影響は無視できない。

(2)その原因は, 散乱線であり, これは透過 X 線 のみによる黒化度を大きく修飾している。

(3)その程度は, ソーセージの厚みによる。

(6) 実際の臨床においても, 以上のようなとと がいえると考えられる。臨床的に確認した。

以上の結果より, 歯周疾患の治療後の歯槽骨の 変化を, X 線写真の黒化度の変化で追究する際に は, 軟組織の存在を無視するてとはできない。影 響の因子として, 軟組織の厚みと散乱線が考えら れる。てれらの影響を避けるために，X線撮影の 際, 照射野をある程度絞って撮影する必要がある ことなどが明らかになった。

\section{謝辞}

稿を終えるにあたり，終始ご指導とご校閲を賜っ た木下四郎教授に対し䔆んで感謝の意を表します。 また終始睤切丁寧なご教授、ご校閲をいただきまし た歯科放射線学教室中村正教授に深く謝意を表しま す。また，実験に際し，ご援助，ご協力をいただき ました歯科放射線学教室の方々および第 2 歯科保存 学教室員各位に感謝いたします。

なお本論文の要旨は, 第19回春季日本蒾周病学会 において発表した。 


\section{文献}

1) Mack, P. B., et al. : Method for estimating degree of mineralization of bones from tracing of roentgenogram. Science, $89: 467$, 1939.

2) Richard, G. : Penetrometers for measuring the radiopacities of tissues. J. Dent. Res., $29: 696,1950$.

3）田治米保夫, 他：柬周疾患におけるX線規格撮 影に関する研究一その 2. Multiplier Photometer を用いての透過度の測定について. 日 本歯槽膿漏学会誌, $9: 39,1966$.

4）川崎 仁：口内法による個体 $X$ 線規格撮影とそ の歯周疾患治療への応用. 口病誌, $34: 164$, 1967.

5) Isenberg., Goldman, H. M., Parson F. G. and Street P. N. : Radiographic analysis by twodimensional microdensitometry. J. Amer. Dent. Ass., 77 : 1069, 1968.

6) Owings, J.R., JR. and Fritz, M.E. : A Technique employing metallic implants for the evaluation of periodontal Surgery. J. Periodontology, $40: 661,1969$.

7) Matsue, I., Collings, C. K., Zimmermann, E. R. and Vail, W. C. : Microdensitometric analysis of human autogenous alveolar bone implants. J. Periodontology, $41: 489,1970$.

8）松江一郎, 他：畨周疾患治療における骨移植の Isodensitracer による評価. 日歯保誌，14： 111, 1971.

9) Plotnick, I. J., et al. : A technique for standardized serial dental radiographs. J. Periodontology, $42: 297,1971$.

10）茂木健司：抜歯創の治癔に関するX線学的並び 亿組織学的研究. 口病誌, $38: 33,1971$.

11) Matsue, I., Zimmermann, E. R., Collings, C. K. and Best, J. T. : Microdensitometric analysis of human autogenous bone implant. Two-dimensional density and pattern analysis of interproximal alveolar bone. J. Periodontology, $42: 435,1971$.

12）清水欽也, 他：雬石除去の研究 (5)函石除去後 の歯槽骨頂部の変化について. 日歯周誌， 14 :
85, 1972.

13) Updegrave, W. J.: The paralleling extention cone technique in intraoral dental radiography, Os. Om. Op., $4: 1250,1951$.

14) Harndt, E. : Das Röntgenbild des alveolar Kammes. D. Z. Z.. $12: 1635,1957$.

15) Patur, B. and Glickman, I. : Clinical and röntgenographic evaluation of the post treatment healing of infrabony pockets. J. Periodontology, $33: 164,1962$.

16) Houwink, B. and Backer, D. O. : A Reproducible Method for Radiographic Diagnosis of Calculus on Proximal Surfaces. J. Periodontology, 36:239, 1965 .

17）田治米保夫, 他：曾周疾患におけるX線規格撮 影関する研究一その 1 - . 歯科医学, 29 : 120, 1966.

18) Boyle, W. D., Jr, et al. : Radiographic analysis of alveolar crest height. J. Periodontology, $44: 236,1973$.

19）奥山武雄 : 骨 $X$ 線像の定量的観察についての研 究. 日医放会誌, $25: 775,1965$.

20）島野達也：歯科口内法X線撮影において読像に 影響を及ぼす基礎的因子について. 歯科学報, $63: 167,1963$.

21) Austin L. T. : The penetrometer in dental roentgenography. J. Amer. Dent. Ass., 21 : 2021, 1934.

22) Manson-Hing, L. R. : An investigation of the roentgenographic contrast of enamel, dentine and aluminum. OS. OM. OP., 14 : $1456,1961$.

23）藤田恒太郎：歯の組織学, 東京, 1957 , 医歯薬 出版, 180ページ.

24）上條雍彦: 図説口腔解剖学 5. 内蔵学. 東京, 1969, アナトーム社, 1234ページ。

25）安藤正一：5.読影論，古本啓一他，苗界展望別 冊歯科 X 線診査. 東京, 1970, 医歯薬出版, 86 ペーシ.

26）宮川 正, 他：ターポゴシアン放射線診断の物 理. 東京, 1970, 朝倉書店, 44ページ.

27）宮川 正, 他：ターポゴシアン放射線診断の物 理. 東京, 1970 , 朝倉書店, $251,269,272$ ヘ - シ. 